\title{
Interaction and dose equivalence of salbutamol and salmeterol in patients with asthma
}

\author{
E T Smyth, I D Pavord, C S Wong, A F Z Wisniewski, J Williams, A E Tattersfield
}

\section{Abstract}

Objective-To examine the pharmacological interaction of salmeterol and salbutamol and to derive an estimate of dose equivalence of salmeterol for airway and systemic effects in patients with asthma.

Design-Randomised double blind crossover study.

Subjects -12 patients with mild asthma.

Intervention-Placebo or salmeterol 50, 100, $200 \mu \mathrm{g}$ given on separate days followed two hours later by inhaled salbutamol in cumulative doses up to $3600 \mu \mathrm{g}$.

Main outcome measures-Change in forced expiratory volume in one second $\left(F_{E V}\right)$, heart rate, plasma potassium concentration, QTc interval, tremor amplitude, and creatine kinase myocardial isoenzyme concentration.

Results-Compared with placebo, the mean (95\% confidence interval) changes in $\mathrm{FEV}_{1}$ and heart rate after salmeterol $200 \mu \mathrm{g}$ were $0.61(0.32$ to 0.90$) 1$ and 7.0 (3.8 to 10.2$)$ beats $/ \mathrm{min}$. Adding salbutamol caused a large increase in $\mathrm{FEV}_{1}$ after placebo (0.69 1) with progressively smaller changes after increasing doses of salmeterol (0.19 1 after salmeterol $200 \mu \mathrm{g})$. Heart rate and QTc interval increased and plasma potassium concentration decreased roughly in parallel on the four study days with a suggestion of convergence at higher doses of salbutamol. Geometric mean dose equivalences for salmeterol $50 \mu \mathrm{g}$ and $100 \mu \mathrm{g}$ compared with salbutamol were 4.9 and 7.8 (mean 6.4) for FEV 1 and ranged from 7.1 (2.9 to $17.0)$ to $12.6(4.4$ to 36.4$)$ for heart rate, plasma potassium, and tremor (mean 9.5).

Conclusions-The effect of adding salbutamol to salmeterol is largely additive. Weight for weight salmeterol may be up to 10 times more potent than salbutamol. Considering its longer duration of action salmeterol $50 \mu \mathrm{g}$ twice daily could be equivalent to salbutamol in doses up to $500 \mu \mathrm{g}$ four to six hourly.

Respiratory Medicine Unit, City Hospital, Nottingham NG5 1PB

E T Smyth, research fellow I D Pavord, lecturer C S Wong, research fellow A F Z Wisniewski, research assistant

J Williams, research assistant A E Tattersfield, professor of respiratory medicine

Correspondence to: Professor Tattersfield.

BMF 1993;306:543-5 dilatation as 200 a salbutamol.16 This shows the insensitivity of single dose comparisons as a method of estimating relative potency. The importance of knowing the dose equivalence of $\beta_{2}$ agonists is highlighted by the recent experience in New Zealand, where the excess mortality associated with fenoterol ${ }^{1-9}$ has been attributed to marketing of a metered dose inhaler that contained a two to four times higher relative dose of fenoterol compared with salbutamol. ${ }^{10}$

It is recommended that salmeterol be taken regularly twice daily and that a shorter acting $\beta_{2}$ agonist such as salbutamol be added for additional relief. ${ }^{11}$ The effect of combining the two agonists, however, has received little attention. Salmeterol is a partial agonist in vitro compared with salbutamol ${ }^{12}$ and could therefore reduce the access and effectiveness of salbutamol by occupying $\beta$ receptors. We studied the effect of adding increasing doses of salbutamol to salmeterol 50,100 , and $200 \mu \mathrm{g}$ to examine the drugs' interaction and estimate dose equivalence.

\section{Subjects and methods}

We studied 12 subjects (three women) aged 18-54 years with asthma but no other medical problems. All were lifelong non-smokers, had a normal electrocardiogram, a baseline forced expiratory volume in one second $\left(\mathrm{FEV}_{1}\right)$ greater than $60 \%$ predicted, and at least a $15 \%$ rise in $\mathrm{FEV}_{1}$ after $400 \mu \mathrm{g}$ inhaled salbutamol. All were taking an inhaled short acting $\beta_{2}$ agonist as required and nine a regular inhaled steroid. Subjects gave informed written consent and the study was approved by the Nottingham City Hospital ethics committee.

$\mathrm{FEV}_{1}$ was measured by dry bellows spirometer with the subject seated and the better of two successive measurements was recorded. Heart rate, QTc interval, tremor, and plasma potassium were measured as described $^{10}$; plasma creatine kinase concentration by the $\mathrm{N}$-acetyl cysteine activated method; and creatine kinase myocardial isoenzyme by immunochemical separation (Isomune-CK, Roche, Welwyn Garden City, Hertfordshire).

Subjects were studied at the same time of day on four occasions at least seven days apart. Inhaled $\beta_{2}$ agonists and drinks containing caffeine were withheld for 12 hours before each study. After 20 minutes' rest baseline heart rate, QT interval, tremor amplitude, $\mathrm{FEV}_{1}$, and plasma potassium and creatine kinase myocardial isoenzyme concentrations were measured. Subjects then received placebo or salmeterol 50,100 , or $200 \mu \mathrm{g}$ by metered dose inhaler according to a randomised, crossover, double blind design (by Latin square randomisation). Two hours later inhaled salbutamol was given in doses of $100,500,1000$, and $2000 \mu \mathrm{g}$ at 20 minute intervals, to give a cumulative dose of $3600 \mu \mathrm{g}$. Doses of salbutamol other than the $100 \mu \mathrm{g}$ dose were administered by putting multiples of $500 \mu \mathrm{g}$ into a spacing device (Volumatic, Allen and Hanburys, Uxbridge, Middlesex) and asking the 
subject to inhale deeply three times. Measurements were taken in the same order at baseline, two hours after placebo or salmeterol, and 15 minutes after each dose of salbutamol. Symptoms were documented before each dose of drug. The study was stopped if symptoms became severe or if heart rate rose above 140 beats per minute. Patients stayed in the department until symptoms settled and heart rate had fallen below 110 beats per minute.

\section{ANALYSIS}

The study had $90 \%$ power to detect a difference in heart rate of 6.5 beats/min according to our previous study. ${ }^{10}$ Baseline, maximum changes, and final measurements on the four study days were compared by analysis of variance with the generalised linear interactive modelling (GLIM) statistical package and expressed as means with $95 \%$ confidence intervals. Symptoms were compared by the $\chi^{2}$ test. Dose equivalence was estimated from the salbutamol dose which caused the same effect as that seen with each dose of salmeterol. This was done by plotting each person's response to each dose of salmeterol on the log dose response curve after placebo and salbutamol for each index. Raw data were used and geometric means and 95\% confidence intervals were calculated with the confidence interval analysis (CIA) statistical package. When the change with salmeterol was above the highest or below the lowest change seen with salbutamol the highest or lowest salbutamol dose was used in the analysis as a censored value.

\section{Results}

Baseline, $\mathrm{FEV}_{1}$, heart rate, plasma potassium concentration, QTc interval, tremor amplitude, and creatine kinase concentration (including myocardial isoenzyme) did not differ significantly at the four visits (table I). All patients completed the full study on all four occasions.

Salmeterol caused a largely dose dependent increase in $\mathrm{FEV}_{1}$, heart rate, QTc interval, and tremor amplitude and a fall in plasma potassium concentration (table I, figure). Salbutamol caused a large increase in $\mathrm{FEV}_{1}$ after placebo and progressively smaller increases after salmeterol 50, 100, and $200 \mu \mathrm{g}$ (table I, figure). Heart rate and tremor amplitude increased and plasma potassium concentration decreased roughly in paralle on the four study days (figure). No significant difference was found in the maximum change seen for any

TABLE I-Baseline values of and changes in $F E V_{1}$, heart rate, plasma potassium concentration, QTc interval, and tremor amplitude tzo hours after placebo or salmeterol and maximum change after cumulative doses of salbutamol. Values are mean (SE) unless stated otherwise

\begin{tabular}{|c|c|c|c|c|}
\hline & Placebo & $\begin{array}{l}\text { Salmeterol } \\
50 \mu \mathrm{g}\end{array}$ & $\begin{array}{l}\text { Salmeterol } \\
\quad 100 \mu \mathrm{g}\end{array}$ & $\begin{array}{l}\text { Salmeterol } \\
200 \mu \mathrm{g}\end{array}$ \\
\hline \multicolumn{5}{|l|}{$\mathrm{FEV}_{1}(\mathrm{l}):$} \\
\hline Mean (SD) baseline & $2 \cdot 72(0 \cdot 77)$ & $2 \cdot 56(0 \cdot 76)$ & $2 \cdot 64(0 \cdot 76)$ & $2 \cdot 62(0.67)$ \\
\hline Change from baseline after & & & & \\
\hline $\begin{array}{l}\text { salmeterol/placebo } \\
\text { Change from baseline after salbutamol }\end{array}$ & $0.03(0.07)$ & $0.45(0.08)$ & $0.52(0.08)$ & $0 \cdot 64(0 \cdot 1)$ \\
\hline \multicolumn{5}{|l|}{ Heart rate (beats/min): } \\
\hline Mean (SD) baseline & $68 \cdot 1(9 \cdot 9)$ & $72 \cdot 3(7 \cdot 9)$ & $65 \cdot 8(8 \cdot 6)$ & $67(7 \cdot 3)$ \\
\hline $\begin{array}{l}\text { Change from baseline after } \\
\text { salmeterol }\end{array}$ & & & & \\
\hline salmeterol & $-5 \cdot 4(1 \cdot 8)$ & $-2 \cdot 7(1 \cdot 2)$ & $0.9(1 \cdot 7)$ & $1.6(1.9)$ \\
\hline Change from baseline after salbutamol & $8 \cdot 0(2 \cdot 5)$ & $11.5(1.9)$ & $15 \cdot 1(3 \cdot 0)$ & $14 \cdot 4(1 \cdot 7)$ \\
\hline \multicolumn{5}{|l|}{ Plasma potassium $(\mathrm{mmol} / \mathrm{l})$ : } \\
\hline Mean (SD) baseline & $4 \cdot 17(0.35)$ & $4 \cdot 18(0 \cdot 26)$ & $4 \cdot 16(0 \cdot 23)$ & $4.08(0.27)$ \\
\hline $\begin{array}{l}\text { Change from baseline after } \\
\text { salmeterol/placebo }\end{array}$ & $0.08(0.1)$ & $0.1(0.1)$ & $-0.17(0.09)$ & $-0.05(0.08)$ \\
\hline Change from baseline after salbutamol & $-0.38(0.14)$ & $-0.42(0 \cdot 11)$ & $-0.50(0 \cdot 10)$ & $-0.48(0.05)$ \\
\hline \multicolumn{5}{|l|}{ QTc interval (ms): } \\
\hline Mean (SD) baséline & $280(14)$ & $283(11)$ & $282(17)$ & $281(19)$ \\
\hline $\begin{array}{l}\text { Change from baseline after } \\
\text { salmeterol/placebo }\end{array}$ & $4(3)$ & $6(4)$ & $6(3)$ & $15(4)$ \\
\hline Change from baseline after salbutamol & $40(6)$ & $48(4)$ & $50(9)$ & $51(6)$ \\
\hline \multicolumn{5}{|l|}{ Tremor $\left(\mathrm{cm} / \mathrm{s}^{2}\right)$ : } \\
\hline Mean (SD) baseline & $7 \cdot 8(5 \cdot 5)$ & $8 \cdot 0(4 \cdot 8)$ & $8.9(5 \cdot 0)$ & $8 \cdot 1(3 \cdot 6)$ \\
\hline $\begin{array}{l}\text { Change from baseline after } \\
\text { salmeterol }\end{array}$ & $0 \cdot 2(1 \cdot 0)$ & $0.2(0.8)$ & $1.4(1 \cdot 0)$ & $5 \cdot 2(2 \cdot 1)$ \\
\hline Change from baseline after salbutamol & $6.5(1.8)$ & $7 \cdot 1(1 \cdot 3)$ & $8 \cdot 2(1 \cdot 5)$ & $15 \cdot 3(4 \cdot 7)$ \\
\hline
\end{tabular}
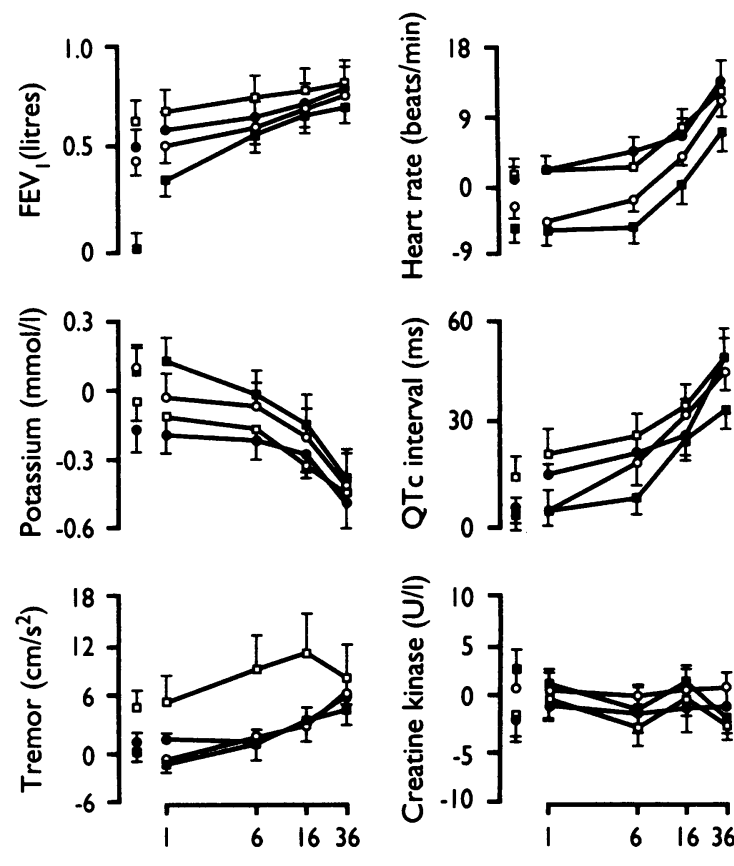

Cumulative dose of salbutamol (puffs)

Mean change from baseline (with standard error bars) in $F E V_{l}$, heart rate, plasma potassium concentration, QT c interval, tremor amplitude, and creatine kinase myocardial isoenzyme concentration two hours after placebo ( ) or salmeterol $50 \mu \mathrm{g}(\mathrm{O}), 100 \mu \mathrm{g}(\bullet)$, or $200 \mu \mathrm{g}$ (ם) and after the addition of increasing doses of salbutamol up to cumulative dose of $3600 \mu \mathrm{g}$

TABLE II - Mean (95\% confidence interval) dose equivalence values for salmeterol compared with salbutamol

\begin{tabular}{|c|c|c|c|}
\hline & $\begin{array}{l}\text { Salmeterol } \\
50 \mu \mathrm{g}\end{array}$ & $\begin{array}{c}\text { Sameterol } \\
100 \mu \mathrm{g}\end{array}$ & $\begin{array}{l}\text { Salmeterol } \\
200 \mu \mathrm{g}\end{array}$ \\
\hline $\begin{array}{l}\text { FEV } \\
\text { Heart rate } \\
\text { Plasma potassium } \\
\text { Tremor amplitude } \\
\text { QTc interval }\end{array}$ & $\begin{array}{r}7 \cdot 8(3.4 \text { to } 17 \cdot 8) \\
9 \cdot 1(3.2 \text { to } 26.4) \\
7 \cdot 1(2.9 \text { to } 17.0) \\
12.6(4.4 \text { to } 36.4) \\
5.8(2.8 \text { to } 12 \cdot 1)\end{array}$ & $\begin{array}{c}4.9(2 \cdot 2 \text { to } 10 \cdot 7) \\
10 \cdot 7(4 \cdot 9 \text { to } 23 \cdot 4) \\
10 \cdot 0(3 \cdot 5 \text { to } 28 \cdot 2) \\
7 \cdot 2(3 \cdot 0 \text { to } 18 \cdot 2) \\
3 \cdot 1(1.3 \text { to } 7 \cdot 2)\end{array}$ & $\begin{array}{l}3.1(1.1 \text { to } 8.9) \\
7.9(3.5 \text { to } 17.3) \\
3.2(1.3 \text { to } 8.3) \\
5.2(2.0 \text { to } 13.2) \\
3.5(1.4 \text { to } 8.7)\end{array}$ \\
\hline
\end{tabular}

of the measures on the four study days (table I). Creatine kinase concentration (including the myocardial isoenzyme) did not increase significantly after salmeterol or salbutamol.

When salmeterol was compared with salbutamol the geometric mean dose equivalence for $\mathrm{FEV}_{1}$, heart rate, plasma potassium concentration, QTc interval, and tremor amplitude ranged from $3 \cdot 1$ to $12 \cdot 6$ (table II). The dose equivalence tended to fall with increasing doses of salmeterol indicating that the responses were tending to plateau with the $200 \mu \mathrm{g}$ dose. The geometric mean dose equivalences for the 50 and $100 \mu \mathrm{g}$ doses were 4.9 and 7.8 (mean 6.4 ) for $\mathrm{FEV}_{1}$ and ranged from $7 \cdot 1$ to 12.6 (mean $9 \cdot 5$ ) for heart rate, tremor, and plasma potassium. The dose equivalence for QTc interval was consistently lower than that for other measures ranging from $3 \cdot 1$ to $5 \cdot 8$ (table II).

One patient developed lower right chest pain and nausea 48 hours after receiving salmeterol $200 \mu \mathrm{g}$, which was attributed to biliary colic. Other symptoms (tremor, headache, and "others") occurred more often with salmeterol $200 \mu \mathrm{g}$ (five, four, and 16 subjects respectively) than with salmeterol $100 \mu \mathrm{g}$ (one, two, 10), salmeterol $50 \mu \mathrm{g}$ (one, two, six), and placebo (one, two, eight), though the differences were not significant.

\section{Discussion}

The British National Formulary recommends that salmeterol is taken twice daily and that a shorter acting $\beta_{2}$ agonist such as salbutamol be added for further relief. ${ }^{11}$ Since few studies have examined the efficacy 
and safety of combining salmeterol and salbutamol we examined the effects of adding salbutamol to salmeterol on the airway response and potential side effects in patients with mild asthma. Measurements were taken when maximal changes in airway and systemic responses would be expected. ${ }^{13-15}$ A $200 \mu \mathrm{g}$ dose of salmeterol was included in addition to the recommended doses of 50 and $100 \mu \mathrm{g}$ to extend the dose range of salmeterol.

Salmeterol caused a largely dose dependent increase in airway and systemic effects, although only salmeterol $200 \mu \mathrm{g}$ increased tremor amplitude and QTc interval. The addition of salbutamol caused a roughly parallel fall in plasma potassium concentration and increase in heart rate, tremor amplitude, and QTc interval confirming a largely additive effect; the dose response curves for salbutamol seemed to converge at higher doses.

Although more potent than salbutamol on human airways, salmeterol is a partial agonist achieving about $70 \%$ of the maximum effect seen with salbutamol. ${ }^{12}$ When a partial and fuller agonist are combined the partial agonist, by occupying receptors, acts as a partial antagonist, thus reducing the effectiveness of the fuller agonist. Salmeterol could therefore reduce the efficacy of salbutamol when the two are given in combination. In vitro, the dose response curve for a fuller agonist in the presence of a partial agonist is shifted to the right with an elevated baseline and a tendency for the curves to converge and cross over with increasing dose. ${ }^{16}$ Experiments in vitro permit maximum stimulation of $\beta$ receptors and relaxation of smooth muscle, which are unlikely to occur in vivo. Although the suggestion of convergence of the dose response curves for salbutamol is in keeping with an interaction between an agonist and a partial agonist, our data suggest that this interaction is unlikely to be large enough to cause a clinically important reduction in beneficial or adverse effects of salbutamol in patients taking salmeterol. Such an interaction, however, remains possible in patients with severe asthma.

\section{DOSE EQUIVALENCES}

This is the first study to compare the beneficial and adverse effects of increasing doses of salmeterol and salbutamol. Single dose comparisons of salmeterol $50 \mu \mathrm{g}$ and salbutamol $200 \mu \mathrm{g}$ have generally shown similar effects on $\mathrm{FEV}_{1}$, heart rate, and tremor, leading to the view that $50 \mu \mathrm{g}$ salmeterol is roughly equivalent to $200 \mu \mathrm{g}$ salbutamol. ${ }^{14}$ One study looking at the protection provided by the two drugs against histamine induced bronchoconstriction suggested a more than fourfold difference in potency. ${ }^{3}$

Our study allowed us to estimate dose equivalence from the dose response findings with salbutamol and salmeterol. The response to cumulative doses of salbutamol was compared with that to non-cumulative doses of salmeterol. The estimate of dose equivalence for $F_{E V}$ is probably conservative since the airway response to salbutamol is greater with cumulative doses. ${ }^{17}$ The use of a spacing device for the higher salbutamol doses increases the amount delivered to the airways and might also underestimate dose equivalence since airway and systemic effects of $\beta_{2}$ agonists are mainly due to inhaled drug. ${ }^{15}$ The dose equivalence for plasma potassium concentration, tremor, and particularly $\mathrm{FEV}_{1}$ fell with increasing doses of salmeterol as would be expected if the responses were reaching a plateau. The values for the 50 and $100 \mu \mathrm{g}$ doses of salmeterol (generally between 8 and 10) may therefore be better estimates of dose equivalence. The lower dose equivalence for QTc interval remains unexplained but may reflect compensatory mechanisms or greater $\beta_{2}$ selectivity of salmeterol.
Salmeterol seems to be up to 10 times more potent weight for weight than salbutamol for effects on heart rate, plasma potassium, and tremor. Thus for peak effects salmeterol $50 \mu \mathrm{g}$ is equivalent to up to $500 \mu \mathrm{g}$ salbutamol. The dose equivalence over 24 hours is more difficult to estimate but since salmeterol has a longer duration of action salmeterol $50 \mu \mathrm{g}$ twice daily may be equivalent to salbutamol $500 \mu \mathrm{g}$ four to six hourly.

Our findings have two important implications. Firstly, studies comparing salmeterol $50 \mu \mathrm{g}$ twice daily with salbutamol $200 \mu \mathrm{g}$ four times a day ${ }^{45}$ are not comparing equi-effective doses and differences between the two drugs may be due to differences in dose rather than differences in drug. Secondly, high doses of $\beta$ agonist are associated with an increased risk of death ${ }^{19}$ and epidemics of death from asthma have been associated with marketing of high doses of $\beta$ agonists. ${ }^{79} 2021$ Whether the relation between high doses of $\beta$ agonists and mortality is causal remains uncertain but until the question is settled the high dose of salmeterol relative to salbutamol must raise some concerns. Further studies are needed to address the dose equivalence of salmeterol and the optimum dose for long term treatment.

We thank Dr J Britton for statistical help, Mrs S Pacey for coding and supplying the drugs, Mrs $M$ Clark for technical support, and Professor I MacDonald and Ms H Parkin for help with tremor analysis.

1 Ullman A, Svedmyr N. Salmeterol, a new long acting inhaled $\beta_{2}$ adrenoceptor agonist: comparison with salbutamol in adult asthmatic patients. Thorax 1988;43:674-8.

2 Derom EY, Pauwels RA, van der Straeten MEF. The effect of inhaled salmeterol on methacholine responsiveness in subjects with asthma up to 12 hours. F Allergy Clin Immunol 1992;89:811-5.

3 Campos-Gongora H, Wisniewski AFZ, Tattersfield AE. A single-dose comparison of inhaled albuterol and two formulations of salmeterol on airway reactivity in asthmatic subjects. Am Rev Respir Dis 1991;144:626-9.

4 Ullman A, Hedner J, Svedmyr N. Inhaled salmeterol and salbutamol in asthmatic patients. Am Rev Respir Dis 1990;142:571-5.

5 Pearlman DS, Chervinsky P, LaForce C, Seltzer JM, Southern DL, Kemp JP, et al. A comparison of salmeterol with albuterol in the treatment of mild-toet al. A comparison of salmeterol with albuterol in

6 Sandström T, Frederiksen B, Rosenhall L, Sandström B. Salmeterol-a dose response study with a long acting inhaled $\beta_{2}$-agonist. Am Rev Respir Dis 1989;139:A64.

7 Crane J, Platt A, Jackson R, Ball M, Pearce N, Burgess C, et al. Prescribed fenoterol and death from asthma in New Zealand, 1981-83: case-control study. Lancet 1989;i:917-22.

8 Pearce N, Grainger J, Atkinson M, Crane J, Burgess C, Culling C, et al. Casecontrol study of prescribed fenoterol and death from asthma in New Zealand, 1977-81. Thorax 1990;45:170-5.

9 Grainger J, Woodman K, Pearce N, Crane J, Burgess C, Keane A, et al. Prescribed fenoterol and death from asthma in New Zealand, 1981-7: a further case-control study. Thorax 1991;46:105-11.

10 Wong CS, Pavord ID, Williams J, Britton JR, Tattersfield AE. Bronchodilator, cardiovascular, and hypokalaemic effects of fenoterol, salbutamol, and cardiovascular, and hypokalaemic effects of
terbutaline in asthma. Lancet 1990;336:1396-9.

11 Joint Formulary Committee. British National Formulary No 24. London: British Medical Association, Pharmaceutical Press, 1992:113.

12 Ball DI, Brittain RT, Coleman RA, Denyer LH, Jack D, Johnson M, et al. Salmeterol, a novel, long-acting $\beta_{2}$-adrenoceptor agonist: characterization of pharmacological activity in vitro and in vivo. Br $\mathcal{F}$ Pharmacol 1991;104: $665-71$

13 Tattersfield AE, McNicol MW. Salbutamol and isoproterenol. A double-blind trial to compare bronchodilator and cardiovascular activity. $N$ Engl f Med 1969;281:1323-6.

14 Flatt A, Crane J, Purdie G, Kwong T, Beasley R, Burgess C. The cardiovascular effects of beta adrenergic agonist drugs administered by nebulisation. Postgrad Med f 1990;66:98-101.

15 Collier JG, Dobbs RJ, Williams I. Salbutamol aerosol causes a tachycardia due to the inhaled rather than the swallowed fraction. $\mathrm{Br} F \mathrm{Clin}$ Pharmacol 1980;9:273-4.

16 Pratt WB, Taylor $P$, eds. Principles of drug action. 3rd ed. New York: Churchill Livingstone, 1990.

17 Britton JR, Tattersfield AE. Comparison of cumulative and non-cumulative techniques to measure dose-response curves for beta agonists in patients with asthma. Thorax 1984:39:597-9.

18 Butchers PR, Cousins SA, Vardley CJ. Salmeterol: a potent and long-acting inhibitor of the release of inflammatory and spasmogenic mediators from human lung. Brf Pharmacol 1987;92:745P.

19 Spitzer WO, Suissa S, Ernst P, Horwitz RI, Habbick B, Cockcroft D, et al The use of $\beta$-agonists and the risk of death and near death from asthma. N Engl F Med 1992;326:501-6.

20 Inman WHW, Adelstein AM. Rise and fall of asthma mortality in England and Wales in relation to use of pressurised aerosols. Lancet 1969;ii:279-85.

21 Stolley PD. Asthma mortality: why the United States was spared an epidemic of deaths due to asthma. Am Rev Respir Dis 1972;105:883-90.

(Accepted 22 December 1992) 